\title{
Toxicity of Pyrethroids to Grapsid Crab (Pseudograpsus sp.) Collected from the Sundarbans Mangrove Ecosystem, Bangladesh
}

\author{
Mst. Muslima Khatun*, Bipul Kimar Nondi, S. Mondal, Md. Mamunur Rashid, \\ Kongchain Marma, Momotaz Khanom, Md. Noman Siddiqui \\ Fisheries and Marine Resource Technology Discipline, Khulna University, Khulna-9208, Bangladesh.
}

*Corresponding Author: Mst. Muslima Khatun, Fisheries and Marine Resource Technology Discipline, Khulna University, Khulna-9208, Bangladesh.

\begin{abstract}
Grapsid crab (Pseudograpsus sp.) was exposed to three synthetic pesticides (pyrethroids eg. cypermethrin, deltamethrin and fenvalerate) to observe the toxicity on this crab. The crabs were exposed to 8 concentrations of cypermethrin, 4 concentrations of fenvalerate and 6 concentrations of deltamethrin and a control. For each treatment there were three replicates and they were stocked in glass aquaria with dechlorinated tap water and aeration at a density of $1 \mathrm{crab} / \mathrm{l}$. Cent percent mortality were recorded at 0.16 ppm and 0.004 ppm for fenvalerate and deltamethrin respectively within 72 hrs. Lethal concentrations (LC 50) for cypermethrin, deltamethrin and fenvalerate to grapsid crab at 48 hrs exposure periods were $0.00332 \mathrm{ppm}$, $0.00137 \mathrm{ppm}$ and $0.06976 \mathrm{ppm}$ respectively; $0.00208 \mathrm{ppm}, 0.00101 \mathrm{ppm}$ and $0.04351 \mathrm{ppm}$ respectively at 72 $\mathrm{hr} ; 0.00068 \mathrm{ppm}, 0.00063 \mathrm{ppm}$ and $0.03020 \mathrm{ppm}$ respectively at $96 \mathrm{hr}$. It was observed from the study that grapsid crabs were susceptible to all of the three pesticides, and deltamethrin was the most toxic.
\end{abstract}

Keywords: Toxicity, Pesticides, Pseudomonas sp., Sundarbans.

\section{INTRODUCTION}

Grapsid crabs play a very important role in the mangrove ecosystem like the Sundarbans. These crabs consuming the tree litters helps in the production of organic matter in the mangrove through their scavenging activity [1]. On an average $28 \%$ of the mangrove forest leaves are consumed by the crabs [2] and helps in turn over the nutrient to the mangrove forest for primary production. Bioturbation also known as sediment re-networking helps to change the surface topography of the mangrove, reduce the particle size and distribution and aeration of the sediment. Bioturbation also helps to reduce the amount of phyto-toxin in the soil and sediment of the forest [3]. Crabs consumed different parts of the mangrove propagules at preferential time and helps in the distribution of mangrove plants in the forest.

Crustaceans and lower aquatic invertebrates are known to serve as the secondary source of food chain [4]. The grapsid crab or Pseudograpsus sp. belongs to the family Grapsidae, genus Pseudograpsus [5] (locally called pati kakra) are found in the canal of the Sundarbans. It is eaten by local people and also used as feed of fish after drying in local fish farm (Personal communication).

About 10 million people live in the coastal region offshore island of Bangladesh [6]. Compare to the other parts of the country, people living in the coastal areas particularly around the Sundarbans Reserve Forest (SRF) are poor. Literacy rate is low. Most of them are anglers, landless laborers and marginal farmers. They catch white fish, shrimp, shrimp fry, mussel and so on [7]. The catch per unit effort using traditional gear is low. They also need to buy the fishing permit from forest department which is also expensive to them. So get more fish within short period of time and to recover the cost of the permit/license, they directly use pesticides in canal. This practice is going on for last several years. In Khulna region, they have been usually using cypermethrin. In absence of cypermethrin, they have been using deltamethrin, fenvalerate and so on (Personal communication). Cypermethrin, deltmethrin and fenvalerate are all in the pyrethoid groups that are reported to usually use against pests of cotton, fruits and vegetables. Pyrethoids a synthetic pesticides is very popular now a days as it's a good substitute of organochlorine, organophosphate and carbamates and also it is effective to wide range of insect species [8]. Fenvalerate also a type of synthetic pesticides widely accepted for its higher potency and quick biodegradability.

Although these insecticides are usually used for killing the target species [9], they are also killing or affecting the non-target species indiscriminately in the applied canals. Crustaceans are claimed to be 
more sensitive to pesticide toxicity than fish and mammals [10-13]. The $96 \mathrm{hr}$. $\mathrm{LC}_{50}$ of mysid (Mysidopsis bahia) is less than $0.01 \mu \mathrm{g} / \mathrm{l}$ for fenvalerate and cypermethrin, while $96 \mathrm{hr}$. $\mathrm{LC}_{50}$ of Penaeus duorarum is $0.036 \mu \mathrm{g} / \mathrm{l}$ and $0.48 \mu \mathrm{g} / \mathrm{l}$ for cypermethrin and fenvalerate, respectively. Furthermore, [12] reported that $100 \mathrm{~g} / \mathrm{ha}$ of cypermethrin is enough for high mortality of aquatic insects and crustaceans though fish survive at this dose. Some studies have examined the effect of pesticides on fish, fish fry and invertebrates [13-15]. However, still now nobody attempt to assess the loss of crab species of the Sundarbans because of using pesticide. No effort is given to determine the $\mathrm{LC}_{50}$ of cypermethrin, deltmetyhrin and fenvalerate on grapsid crabs of SRF. This study was conducted to find out the toxic effect, $\mathrm{LC}_{50}$ of cypermethrin, fenvalerate and deltamethrin on Pseudomonas sp. at 48-h, 72-h and 96-h.

\section{Materials AND Methods}

\subsection{Collection and Stocking of Crabs}

The adult grapsid crabs, Pseudomonas sp. both male and female were collected from coastal water in Mongla, Bagerhat near the Sundarbans, where freshwater streams are flowing [16]. The crabs were covered with straw and banana leaves in bamboo box and transported to the laboratory. Then, the crabs were acclimatized in large tank and stocked in glass aquarium at a stocking density $1 \mathrm{crab} / \mathrm{l}$ for the experiment.

\subsection{Preparation and Application of Test Pesticides}

The study was conducted at the Fish Physiology Laboratory, Khulna University, Bangladesh. The experiment was conducted into two groups. The control group was free from any pesticide. In the exposed groups, eight, six and seven different concentration of cypermethrin, deltamethrin and fenvalerate were used respectively (Fig. 1). The concentrations for cypermethrin were 0.000025 , $0.00005,0.0001,0.0002,0.0004,0.0008,0.0016$ and $0.0032 \mathrm{ppm}$, for deltamethrin were 0.000125 , $0.00025,0.0005,0.001,0.002$ and $0.004 \mathrm{ppm}$, and for fenvalerate were $0.0025,0.005,0.01,0.02,0.04$, $0.08,0.16 \mathrm{ppm}$ (Fig. 1). The pesticides were collected from local pesticide dealer. Three replicates were used for each treatment. Aeration was provided throughout the experimental period. $18 \mathrm{hrs}$ light and 6 hrs dark was used at the time of study, 4 feet florescent tube were used to provide the light. Mortality was recorded at every $12 \mathrm{hrs}$ intervals up to $96 \mathrm{hrs}$.

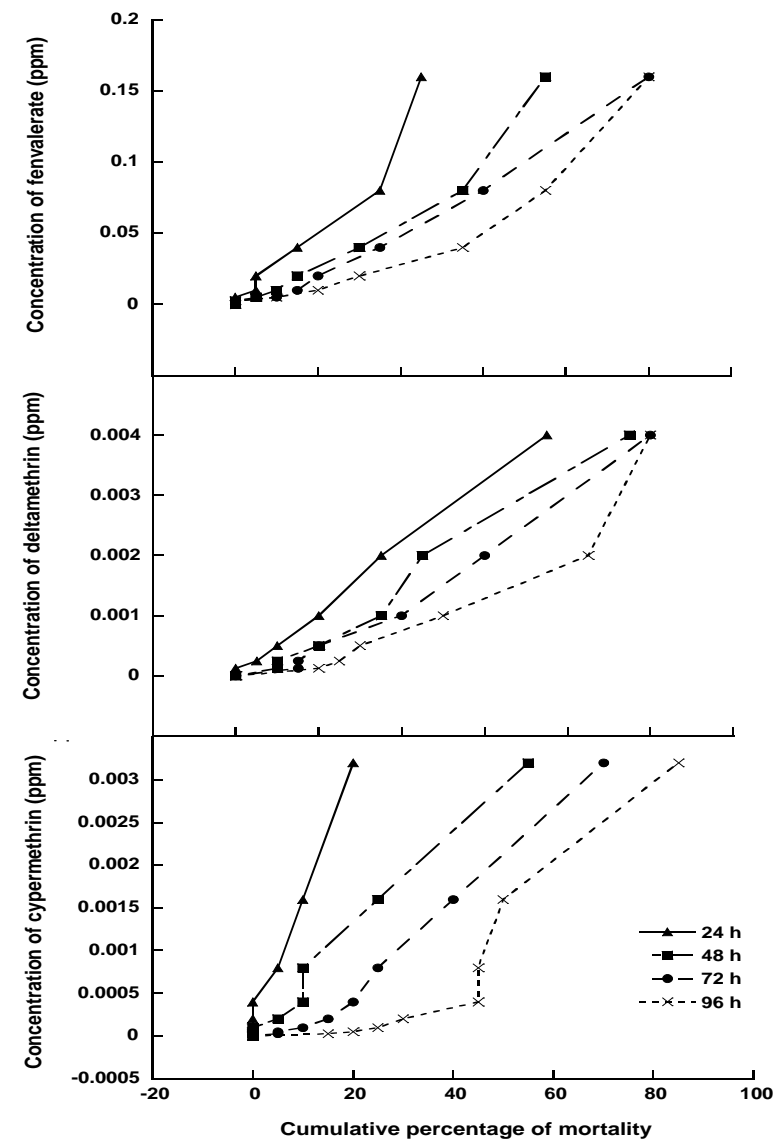

Figure1. Cumulative percentage of mortality of grapsid crab (Pseudograpsus sp.) of different concentrations of Cypermethrin, Deltamethrin and Fenvalerate at different exposure time. 


\subsection{Assessment of Treatment Effect}

The effect of pesticides were measured by counting mortality rate and analyzing $\mathrm{LC}_{50}$. $\mathrm{LC}_{50}$ values (the concentration of toxicant lethal to $50 \%$ of the test organisms in a specified time period) were calculated by probit analysis [17].

\section{RESULTS AND DISCUSSION}

Pesticides are known to cause great deleterious effect on aquatic resources and human. In the present study, $\mathrm{LC}_{50}$ of mangrove grapsid crab (Pseudograpsus sp.) were recorded at $24 \mathrm{hr}$ up to $96 \mathrm{hr}$ for different concentration of cypermethrin, deltamethrin and fenvalerate (Fig. 2). The average weight and carapace width of the crabs were $17.12 \pm 1.69 \mathrm{~g}$ and $2.23 \pm 0.54 \mathrm{~mm}$. The crabs in control group showed normal behavior and was found to be alive during the entire experimental period. Crabs exposed to cypermethrin and other pyrethroids suffered from uncoordinated frequent movements [18]. Initial response of the exposed crabs in the present study was fast movement. After a short period of time, they showed abnormal swimming and movements including failure to maintain the orientation, and later they gathered at one place of the aquaria. Afterward, their movement gradually slowed down and finally settled down at the bottom. [19] in their experiment with Trichodactylus borellianus found that the crab were hyperactive at the beginning and become lethargic at the end of the experiment with cypermethin. This can happen because of changes in metabolic oxygen demands and ammonia $\mathrm{N}$ excretion [20].

In the present study, mortality rates varied with different concentrations and exposure time. It was observed from the mortality data that the mortality of crabs was positively correlated with increasing exposure time and concentration of all pesticides (Fig. 1). No cent percent mortality was found for cypermethrin within the tested concentrations. Cent percent mortality was observed for deltamethrin and fenvalerate at $0.004 \mathrm{ppm}$ and $0.16 \mathrm{ppm}$ respectively for $72 \mathrm{hr}$. Mortality of crabs ranged from 5$55 \%$ at $48 \mathrm{hr}, 5-70 \%$ at $72 \mathrm{hr}$ and $15-85 \%$ at $96 \mathrm{hr}$ exposed to different concentrations of cypermethrin, $10-95 \%$ at $48 \mathrm{hr}, 15-100 \%$ at $72 \mathrm{hr}$ and $20-100 \%$ at $96 \mathrm{hr}$ exposure of different concentrations of deltamethrin, $0-55 \%$ at $48 \mathrm{hr}, 0-60 \%$ at $72 \mathrm{hr}$ and $0-75 \%$ at $96 \mathrm{hr}$ exposure of different concentrations of fenvalerate (Fig. 1). Therefore, the $\mathrm{LC}_{\mathbf{5 0}}$ varied with different pesticides and exposure times. Similar mortality trend is observed in other experiments $[13,14]$ in Limnodrilus sp. and indian major carp with different pesticides. Estimated $\mathrm{LC}_{50}$ values of cypermethrin at various exposure periods were 0.00332 ppm for $24 \mathrm{hr}, 0.00208 \mathrm{ppm}$ for $48 \mathrm{hr}$ and $0.00068 \mathrm{ppm}$ for $96 \mathrm{hr}$ (Fig. 2). LC $\mathrm{L}_{50}$ values of deltamethrin for grapsid crab at $24 \mathrm{hr}, 48 \mathrm{hr}, 72 \mathrm{hr}$ and $96 \mathrm{hr}$ were $0.00237 \mathrm{ppm}, 0.00137 \mathrm{ppm}, 0.00101 \mathrm{ppm}$ and $0.00063 \mathrm{ppm}$ respectively. Regarding another pyrethoid pesticide fenvalerate, $\mathrm{LC}_{50}$ values at $48 \mathrm{hr}, 72$ $\mathrm{hr}$ and $96 \mathrm{hr}$ were $0.06976 \mathrm{ppm}, 0.04351 \mathrm{ppm}$ and $0.03020 \mathrm{ppm}$ respectively (Fig. 2). These results showed that deltamethirn was the most toxic, then cypermethrin and fenvalerate to Pseudograpsus sp. Deltamethrin is often reported to be the most toxic to crustaceans among the pyrethroid insecticides [11]. Cypermethrin also shows more toxic effect than fenvalerate to freshwater crab, Barytelphusa cunicularis [21] and rainbow trout [22]. Regarding pyrethroid toxicity to other aquatic organisms, [23] found that $\mathrm{LC}_{50}$ for grass shrimp (P. pugio) at $96 \mathrm{~h}$ for cypermethrin was as $0.016 \mu \mathrm{g} / \mathrm{l}$. [24] in his study with $P$. duorarum found that the $96-\mathrm{h} \mathrm{LC}_{50}$ values of cypermethrin and fenvalerate were $0.11(0.089-$ $0.13)$ and $0.84(0.66-1.2) \mu \mathrm{g} / \mathrm{l}$ respectively. [15] stated the $96 \mathrm{hr} \mathrm{LC}_{50}$ values of cypermethrin to some species of fish (C. carpio. S. erythrophthalmus, S. gairdneri, S. trutta and T. nilotica) range 0.4-2.2 $\mu \mathrm{g} / \mathrm{l}$. The $96 \mathrm{hr} \mathrm{LC}_{50}$ values of fenvalerate to the grass shrimp, P. pugio range from 0.007 to $0.071 \mu \mathrm{g} / \mathrm{l}$ [25]. The $\mathrm{LC}_{50}$ value of fenvalerate to C. carpio ( $48 \mathrm{hrs)}$ are $0.030 \mathrm{ppm}$ [26]. The amphipod E. estuarius had acute 96-hr $\mathrm{LC}_{50}$ values for deltamethrin between 1.66 to $7.99 \mathrm{ng} / \mathrm{l}$ and sand shrimp had acute 96 $\mathrm{hr} \mathrm{LC}_{50}$ for formulated deltamethrin from $27.4 \mathrm{ng} / \mathrm{l}$ [11].

The mortality from the exposure of three pesticides was different in the current study. Pesticides create stress on the aquatic organisms and change the biochemical and physiological condition of the body. Organisms all the time not able to cope up with the changes as a result they can die [21]. Different studies show that pesticides can act as hypo or hyper enzymatic toxicant. Because of pesticide exposure, enzyme responsible for anaerobic metabolism goes up and enzyme responsible for aerobic metabolisms goes down in the gill and hemolymph of crustacean [27]. Cypremethrin bounds with membrane enzyme and destroys the mitochondria, that causes decrease respiration in the organisms [18]. 


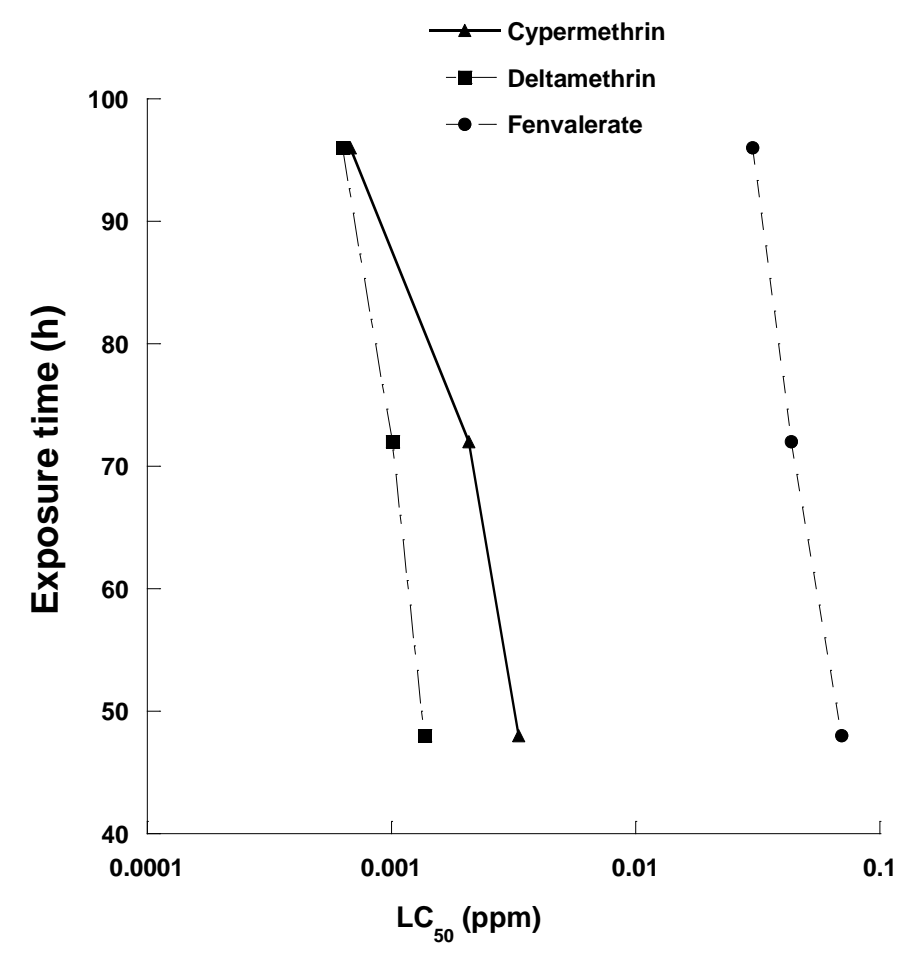

Figure2. Lethal concentration $\left(L_{50}\right)$ of cypermethrin, deltamethrin and fenvalerate at different exposure time.

\section{CONCLUSiON}

From the present study, it seems that pyrethroid pesticides exposure to the crab caused toxic effects and the grapsid crabs are more susceptible to deltamethrin toxicity because the $48 \mathrm{hr}, 72 \mathrm{hr}$ and $96 \mathrm{hr} \mathrm{LC}_{50}$ value for this pesticide is less than cypermethrin and fenvalerate. Since the Sundarbans mangrove region is nursery ground of crab larvae in Bangladesh, pesticide fishing and indiscriminate uses of pesticides in agricultural lands can cause serious threat to crabs. Moreover, such crabs that have accumulated pyrithroid pesticides in their body can be transferred to higher organisms including human through food chain. Pyrithroid pesticides induced acute toxicity could be used to study the physiological and biochemical changes of the crab and can be implemented in policy making and future project development.

\section{REFERENCES}

[1] Macintosh D. J. (1984) Ecology and productivity of Malaysian mangrove crab populations (Decapoda: Brachyura). In: Soepadmo E, Rao AN, Macintosh DJ, editors. Proceedings of the Asian Symposium on Mangrove Environment Research and Management; Kuala Lumpur: University of Malaya and UNESCO. p. 354-77.

[2] Robertson A. I. (1986) Leaf-burying crabs: their influence on energy flow and export from mixed man grove forests (Rhizophora sp.) in northeastern Australia, Journal of Experimental Marine Biology and Ecology and Society. vol. 102:237-48.

[3] Lee S. Y. (1998) Ecological role of grapsid crabs in mangrove ecosystems: a review, Mar Freshwater Res. vol. 49:335-43.

[4] Santharam K., Thayumanavan B., Krishnaswamy S. (1976) Toxicity of some insecticides to Daphnia carinata King, an important link in the food chain in the freshwater ecosystems, Indian Journal of Ecology. vol. 3(1):70-3.

[5] Masagca J. T. (2011) Occurrence of arboreal-climbing grapsids and other brachyurans in two mangrove areas of southern luzon, Philippines, Biotropia. vol. 18(2):61 - 73.

[6] Siddiqi N. A. (2001) Mangrove Forestry in Bangladesh. University of Chittagong: Institute of Forestry \& Environmental Sciences.

[7] Rouf M. A., Jensen K. R. (2001) Coastal fisheries management and community livelihood possible strategy for the Sundarbans, Bangladesh.

[8] Elliott M., Janes N. F., Rettor C. (1978) The future of pyrethroids in insect control, Ann Rev Ent vol. 23:44369. 
[9] Bradberry S. M., Cage S. A., Proudfoot A. T., Vale J. A. (2005) Poisoning due to pyrethroids, Toxicol Rev. vol. 24(2):93-106. Epub 2005/09/27. PubMed PMID: 16180929.

[10] Clark J. R., Goodman L. R., Borthwick P. W., Patrick J. M., Cripe G. M., Moody P. M., Moore J. C., Lores E. M. (1989) Toxicity of pyrethroids to marine invertebrates and fish: A literature review and test results with sediment-sorbed chemicals, Environmental Toxicology and Chemistry. vol. 8(5):393-401. doi: 10.1002/etc.5620080505.

[11] Fairchild W. L., Doe K. G., Jackman P. M., Arsenault J. T., Aubé J. G., Losier M., Cook A. M. (2010) Acute and chronic toxicity of two formulations of the pyrethroid pesticide deltamethrin to an amphipod, sand shrimp and lobster larvae. Canadian Technical Report of Fisheries and Aquatic Sciences 2876.

[12] Crossland N. O. (1982) Aquatic toxicology of cypermethrin. II. Fate and biological effects in pond experiments, Aquatic Toxicology. vol. 2(4):205-22.

[13] Kabir S. M. H., Khatoon N. (1980) Toxicity of some common insecticides to Limnodrilus sp. (Ologochaeta: Tubificidae), Bangladesh Journal of Zoology. vol. 8(1):61-7.

[14] Alam M. A. G., Al-Arabi S. A. M., Halder G. C., Mazid M. A. (1995) Toxicity of diazinon of the fry on indian major carp Cirhina mrigala (Hamilton), Bangladesh Journal of Zoology. vol. 23(2):183-6.

[15] Stephenson R. (1982) Aquatic toxicology of cypermethrin. I. Acute toxicity to some freshwater fish and invertebrates in laboratory tests, Aquatic Toxicology. vol. 2(3):175-85.

[16] Hoque M. A., Sarkar M. S. K. A., Khan S. A. K. U., Moral M. A. H., Khurram A. K. M. (2006) Present status of salinity rise in Sundarban area and its effect on Sundari (Heritiera fomes) species, Research Journal of Agriculture and Biological Sciences. vol. 2:115-21.

[17] Finney D. J. (1964) Probit analysis: a statistical treatment of the sigmoid response curve. Cambridge, England: Cambridge: Cambridge University Press.

[18] Junquera P. (2014) Cypermethrin: Safety summary for veterinary use on dogs, cats, cattle, sheep, goats, swine and poultry. poisoning, intoxication, overdose, antidote.

[19] Williner V., Collins P. (2003) Effects of Cypermethrin on the Freshwater Crab Trichodactylus borellianus (Crustacea: Decapoda: Braquiura), Bull Environ Contam Toxicol. vol. 71(1):106-13. doi: 10.1007/s00128003-0152-8.

[20] Nielsen A., Hagerman L. (1998) Effects of short-term hypoxia on metabolism and haemocyanin oxygen transport in the prawns Palaemon adspersus and Palaemonetes varians, Mar Ecol Prog Ser. vol. 167:177-83.

[21] Joshi P. P., Kulkarni G. K. (2011) Cypermethrin and fenvalerate induced protein alterations in freshwater crab Barytelphusa cunicularis, Recent Research in Science and Technology. vol. 3(12):7-10.

[22] Haya K. (1989) Toxicity of pyrethroid insecticides to fish, Environmental Toxicology and Chemistry vol. 8(1):381-91.

[23] Clark J. R., Jr. P., J.M., Moore J. C., Lores E. M. (1987) Waterborne and sediment-source toxicities of six organic chemicals to grass shrimp (Palaemonetes pugio) and amphioxus (Branchiostoma caribaeum), Arch Environ Contam Toxicol. vol. 16:401-7.

[24] Cripe G. M. (1994) Comparative acute toxicities of several pesticides and metals to Mysidopsis bahia and postlarval Penaeus duorarum Environmental Toxicology and Chemistry. vol. 13(11):1867-72.

[25] Baughman D. S., Moore D. W., Scott G. I. (1989) A comparison and evaluation of field and laboratory toxicity tests with fenvalerate on an estuarine crustacean, Environmental Toxicology and Chemistry. vol. 8(5):417-29. doi: 10.1002/etc.5620080508.

[26] Reddy M. P. Effect of synthetic pyrethroids on the selected physiological aspects of the common carp, Cyprinus carpio [ PhD]. Anantapur, India: Sri Krishnadevaraya 1988.

[27] Sreenivasan R. S., Moorthy P. K., Deecaraman M. (2011) Cypermethrin induced toxicity to phosphatases and dehydrogenases in gills and hemolymph of fresh water crab, Spiralothelphusa hydrodroma (Herbst), Int J Biol Med Res. vol. 2(3):784-8.

Citation: M. Khatun et al., "Toxicity of Pyrethroids to Grapsid Crab (Pseudograpsus sp.) Collected from the Sundarbans Mangrove Ecosystem, Bangladesh", International Journal of Research Studies in Biosciences (IJRSB), vol. 6, no. 3, pp. 6-10, 2018. http://dx.doi.org/10.20431/2349-0365.0603002

Copyright: (C) 2018 Authors. This is an open-access article distributed under the terms of the Creative Commons Attribution License, which permits unrestricted use, distribution, and reproduction in any medium, provided the original author and source are credited. 